\title{
Development of Introduction to Linguistics' Textbook for English Education Students University of Muhammadiyah Gresik
}

\author{
${ }^{1}$ Riska Widiyanita Batubara \\ English Education Department, Universitas Muhammadiyah Gresik, East Java, Indonesia, \\ E-mail: riskabatubara@umg.ac.id \\ ${ }^{2}$ Amrin Batubara \\ English Education Department, Universitas Muhammadiyah Gresik, East Java, Indonesia, \\ E-mail: amrinbatubara@umg.ac.id \\ ${ }^{3}$ Tri Yuli Ardiyansah \\ English Education Department, Universitas Muhammadiyah Gresik, East Java, Indonesia, \\ E-mail: $\underline{\operatorname{ardi13@umg.ac.id}}$
}

\begin{abstract}
This study aimed to develop textbook for Introduction to Linguistics subject for 4th semester English Department students in the Faculty of Teacher Training and Education University of Muhammadiyah Gresik. Students who take this subject often find it challenging to understand the materials as they are not equipped with the textbook; therefore this study was conducted. This study was a Research and Development (R\&D) study on the textbook of Introduction to Linguistics, using the Four-D (4D) model, which includes (1) Define, (2) Design, (3) Develop and (4) Disseminate. Data was collected through observation, questionnaire as well as unstructured interview. The results showed that textbook draft of Introduction to Linguistics has suited the percentage of media validation from material and teaching media experts by $93.3 \%$ and $95.4 \%$, respectively. From the validation result, it is concluded that this textbook can be perfected and used.
\end{abstract}

Keywords: Textbook development; Introduction to Linguistics textbook; R\&D

\section{Introduction}

The learning process includes interaction between students and teachers and learning sources within a learning environment. This has been stated in the Regulations No. 20 of 2003 about National Education System article 1 paragraph 20. The interaction between students and teachers is essential and must be facilitated well. Indeed in the interaction process in the learning environment, teaching materials must be present to facilitate the achievement of the learning process's objectives. According to Tomlinson (1998), teaching materials are any kinds of material used by teachers and students to facilitate language learning to increase language knowledge and or language experience. Sahertian (2004), in his study, stated that teaching materials have a significant role in realizing quality learning goals. In addition, Tiwari (2008) also stated that teaching materials are tools to get to the learning goals that facilitate classroom management tasks and mentoring students in the learning process.

Richards and Schmidt (2002) stated that with teaching materials, students will feel that they have definite goals that they must achieve in a specific learning process. This is also supported by Choudhury (1998), who stated earlier in his study that teaching materials act as a critical tool of the whole teaching and learning process, which if packaged as a system, teaching materials will be used as a control in the learning process to avoid repetition or missing elements in the 
process in the classroom. Therefore, it can be concluded that a learning process with teaching materials will obtain the learning outcomes better than the one without the teaching materials.

Teaching materials can take many forms, both visuals such as textbooks and audiovisuals such as instructional or tutorial videos, or other forms. In the learning process, textbooks are essential to have as a primary reference for carrying out the learning process. Of course, with technological advances, students can easily find materials in the form of videos or documents to study independently. Still, the existence of textbooks is vital as a reference for students to learn. Hutchinson and Torres (1994) suggest that textbooks are a universal learning element (of learning English). In the learning process, especially in higher education, textbooks are mandatory as a reference for students to look for independent study materials. This is because there are thousands or even millions of learning materials scattered in cyberspace that can be accessed independently by students so that students must have specific focuses on each subject, making it easier for them to find study materials.

In the English Language Education program, students have the freedom to access learning materials via the internet. However, in reality, students of the English Education study program, especially students of the University of Muhammadiyah Gresik, are still unable to sort out the material for them to study in each subject, so textbooks are important and must be available each subject. This textbook will become a guideline for students to continue their independent learning. Unfortunately, in the English Language Education program University of Muhammadiyah Gresik, several courses do not have textbooks. One of the courses that students of the English Education program must take is the Introduction to Linguistics course. The Introduction to Linguistics course is an introductory linguistics course that the English Language Education students must study in the fourth semester. This course is essential for English Language Education students because students who will later become English teachers must know English linguistics basics to explain and teach English to their students.

Based on observations on the implementation of the Introduction to Linguistics course in the English Language Education program, there are several problems found in the learning process. Those problems include (1) students do not have a textbook for the Introduction to Linguistics course so that in learning still uses foreign reference books, (2) the students' English language skills are inadequate to read and understand reference books for the Introduction to Linguistics course written by foreign language experts. Therefore students do not understand the basic knowledge of linguistics that they should be good at in this course.

To provide a solution to this problem, it is necessary to research the Development of Textbooks for Introduction to Linguistics in the English Language Education Program, Faculty of Teacher Training and Education (FKIP), University of Muhammadiyah Gresik. In the development of textbooks, it is necessary to study how the learning process and teaching materials used in the course Introduction to Linguistics FKIP University of Muhammadiyah Gresik and how to develop textbooks for these courses.

\section{Literature Review \\ Introduction to Linguistics}

Introduction to Linguistics is a compulsory subject that must be taken by students of the 4th semester of English Language Education program. This course will explain the basics of language science in English that must be mastered by students who will later become prospective English teachers. This course is compulsory, and students must pass this course before continuing the Applied Linguistics course in the following semester. In the previous period, the Introduction to Linguistics course was given as an introductory subject to linguistics to students of the English department before further dissecting each linguistic study branch in specific classes for each component. However, students of the English Language Education program are only equipped with essential linguistics or linguistics in this course without other linguistic studies courses.

The Introduction to Linguistics course is essential because as a prospective English teacher, students of the English Education study program must know and understand English's basic science before finally teaching their students. Many English teachers are not equipped with sufficient linguistic or linguistic knowledge so that in practice, when teaching, they do not know and are confused when faced with various questions related to the language itself. For example, when a student asks why [i] sound in the word "I" is read/aI/ while the in the word fish, it is read as / fif/, many teachers fail to answer the question. Or when there are questions about the origin of a new word, for example, where the word blog comes from, many English teachers have difficulty finding the word-formation source. Even if they have a solid foundation of linguistics, various questions about the language will be easily explained on a precise basis. Therefore, linguistics becomes mandatory to equip prospective English teacher students. The various branches of linguistics that are the subject of the study of the Introduction to Linguistics course are the primary branches that must be understood. Apart from the origin of language and how the human brain processes language, several linguistics branches such as phonetics, phonology, morphology, syntax and semantics are mandatory topics to be studied in this course. In addition, students will also be provided with pragmatics, discourse analysis, sign language and written history, as well as provisions for students to explore linguistics in English.

\section{Textbooks}


According to Mintowati (2003), textbooks are one of the means for the success of the teaching and learning process. A textbook is a unit of learning that contains information, discussion and evaluation. Books that are arranged systematically will make it easier for students in the material to support the achievement of learning objectives. Therefore, textbooks must be structured in a systematic, attractive manner, have high readability aspects, are easy to digest, and comply with applicable writing rules.

A textbook is a written work in the form of a book used by teachers in the teaching and learning process (Lubis, 2004). Based on the definition of the textbook above, it is concluded that what is meant by a textbook is a written book in a certain field, a standard book used by teachers and students in the teaching and learning process for instructional purposes. The textbook should be equipped with teaching tools that the reader can easily understand in schools and colleges to support the teaching program.

According to Arifin (2009), several essential elements in the definition of textbooks include: 1) textbooks are textbooks that are shown for students at certain levels; 2) textbooks are always related to particular subjects; 3) textbook is a standard book; 4) textbooks written for specific instructional purposes; 5) textbooks are written to support a particular teaching program.

\section{Principles of Textbook Writing} namely:

Based on the guidelines for writing textbooks, Degeng (2001) explains the principles of making textbooks,

1. The principle of relevance (linkage). Textbook material should be relevant or related to the achievement of educators' competencies. If the expected competence is to be mastered by the ability to design learning activities (RPP), then the book's contents must be matters related to the design of learning activities.

2. The principle of consistency. Textbook material should contain linear material/discussion from beginning to end.

3. The principle of sufficiency. The material written in the textbook is adequate (not too little and not excessive) to explain matters related to the competencies or sub-competencies selected as the theme, both the components and the area. This is related to the breadth of the material identified through the concept map.

4. Systematics. Textbooks should be a complete set of information, consisting of interrelated components (discussions) and arranged coherently following the rules for writing textbooks.

\section{Textbook Writing Techniques}

According to Bendor (2007), textbook writing can be done with several techniques, which in general, there are 3 (three) textbook writing techniques, namely:

1. Writing by themselves, the author compiles textbooks based on their ideas and experiences.

2. Repackaging the information. The author does not compile the textbook himself from scratch but uses existing books, textbooks, papers, and other information.

3. Compile writings from various sources related and relevant to the theme.

Textbook writers can use one of the three textbook writing techniques above by prioritizing originality.

\section{Textbook Writing Rules}

Based on the guidelines for writing textbooks (BPSDMP-PMP) in 2012, there are several rules for writing textbooks, which need to be considered by textbook writers. These rules are as follows.

1. The appearance of the book is attractive, moving students to read it;

2. Using standard language and easy to understand;

3. Book structure: short title, attractive layout, coherent order of contents, there is a table of contents and clear cognitive structure

4. Testing understanding, allowing readers to know the progress of learning and critical thinking, there are summaries and exercises that readers must do;

5. Readability, using standard font types and sizes that are not too small or too big and easy to read, sentences and paragraphs are arranged in a structure that is easy to understand;

Writing ethics, fulfilling scientific employees' rules and ethics, not plagiarizing or taking essays, opinions, etc. from others and making them appear as if they wrote it themselves (plagiarism) because they can be considered a copyright issue. Textbook writers must include the source of the writings cited by the rules for writing scientific papers.

\section{Method}

Research on the development of textbooks Introduction to Linguistics uses a Research and Development approach. $\mathrm{R} \& \mathrm{D}$ is a process or steps to develop a new product or improve existing and accountable products. Research on the development of textbooks Introduction to Linguistics refers to the Four-D (4D) research and development model proposed by Thiagarajan, Semmel and Semmel (Trianto, 2010: 189). This development model consists of 4 stages: define, design, develop, and disseminate. 
The define stage is carried out as a preliminary study process. At this stage, the authors conducted a needs analysis in developing the Introduction to Linguistics textbook. This stage is carried out to find out what kind of textbooks are needed by lecturers and students in these courses. The design stage is the design of the Introduction to Linguistics textbook, in which the author designs the material to be included in the textbook by adjusting the material listed in the learning syllabus of this course. The next stage is develop, the writer compiles and expands the material in the textbook. In this stage, the author develops so that the textbook is accessible for students to understand. Because the author takes material from various sources, it is necessary to make adjustments to the book being developed. Rothwell and Kazanas (2004) suggest several steps that can be taken in developing textbooks that are generated by selecting, modifying or designing teaching materials, namely:

a) Prepare an outline of the teaching material

b) Conduct research

c) Testing the available teaching materials

d) Modify existing teaching materials

e) Making new teaching materials

f) Select and provide learning activities

Then the last stage is the disseminate stage or spread. At this stage, the author distributes textbooks to small groups of students and lecturers in the Introduction to Linguistics course.

\section{Research subject}

This study aims to develop a textbook for the Introduction to Linguistics subject for 4th-semester students of the English Education study program. Therefore, there are several subjects in this study: author and book designer, evaluator, student, lecturer, and organization (Richey \& Klein, 2007).

In this study, the author, book designer, and lecturer in the Introduction to Linguistics course are the same person, which is the researcher herself. Also, book evaluators who evaluate and provide input on textbooks in terms of content, layout, and language used. The next subject is students who will later use this textbook, namely students in semester 4 of the English Education study program. The last is the organization, which in this case is the University of Muhammadiyah Gresik.

\section{Data Collection}

In this textbook development research, researchers used two instruments, questionnaires and interviews.

1. Questionnaire

The questionnaire used in this study was an open-ended questionnaire by Likert (1932). This questionnaire is addressed to students as well as to evaluators. The questionnaire, which is intended for students, aims to determine the students' need for textbooks. This questionnaire includes questions about what kind of textbook Introduction to Linguistics is needed and can be easily understood by students and lecturers who teach the course. The second questionnaire is for evaluators who assess and provide suggestions regarding textbook improvements that researchers will make.

2. Interview

Interviews are used to obtain data from evaluators regarding the textbooks being developed. The interview technique used was unstructured interviews, where the authors did not use the interview question guidelines that had been systematically compiled. This interview aims to explore deeper data from the evaluators because not all data can be obtained from the questionnaire. By interviewing the evaluator, it is hoped that there will be constructive feedback for the improvement of the textbooks being developed.

\section{Findings and Discussion}

The definition stage is carried out by conducting literature studies and field studies to determine lecturers and students' needs for the Introduction to Linguistics textbook. The lecturers and students' responses to previously used textbooks, The Study of Language by George Yule and Introduction to Language, 9th Edition by Victoria Fromkin, show that students still find it challenging to understand the material presented. There are several responses related to student difficulties, including difficulty understanding the material due to the language used. Even though students taking the Introduction to Linguistics course are in their $4^{\text {th }}$ semester, in reality, the students' English skills are still relatively low. When students have to read foreign reference books, many still find it challenging to understand the material.

The response from the lecturer who taught this course also concluded the same thing. Another response is the incompleteness of the topics discussed in the reference books previously used. This makes lecturers look for several other references, which are also more challenging to understand. Students are also still reluctant to look for material themselves. Hence, lecturers need a textbook that covers all the topics that must be taught and uses English that is easy and clear enough in the explanation so that students will quickly understand the required material.

Of the three different textbooks writings, the author determines that the Introduction to Linguistics textbook will be made by repackaging existing information. The materials that are already in the reference book related to this course are then developed according to students' needs. In developing textbooks, an analysis of the teaching materials used 
previously was carried out. This analysis is carried out by reading the Introduction to Linguistics course syllabus and cross-checking the essential competencies that students must have. After analyzing the teaching materials, a textbook draft is made.

The textbook Introduction to Linguistics which is compiled, consists of 12 chapters of learning material. The textbook that has been developed needs to be seen as well. Below are the validation results from material experts:

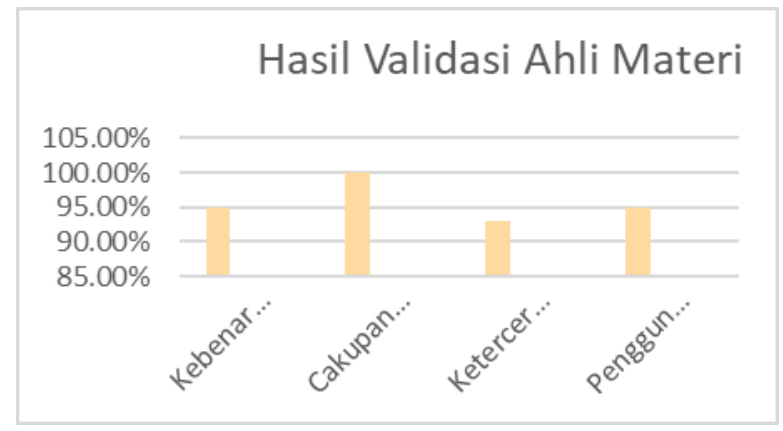

Based on the validation results from material experts, it was found that the draft of the Introduction to Linguistics textbook that was developed had covered all the material that was following the syllabus well. The use of the language used is also considered good enough to make students understand the textbook.

In addition to validating material experts, media experts also validate textbook drafts. The results are as follows:

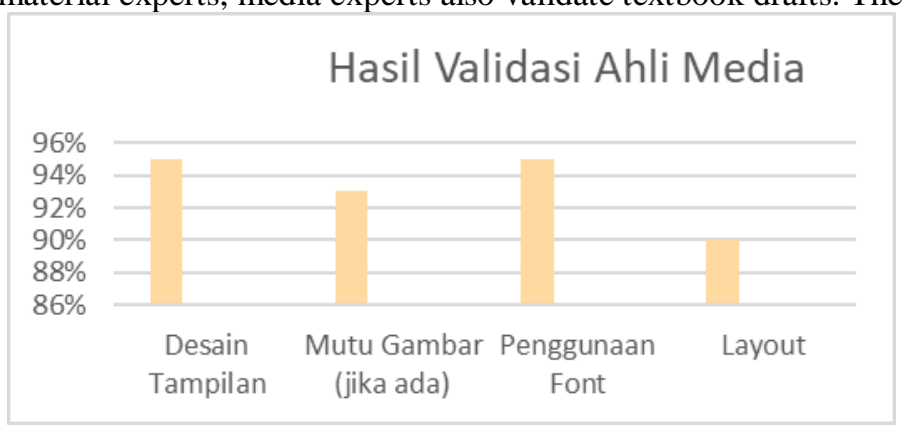

Textbook media experts suggest that each chapter's material should be provided with good pictures that can be used to clarify the material provided. Typing textbooks should also use a particular application for making books, namely the Adobe Design application program. Also, media experts suggest that the type of paper size used to print this textbook is B5 size paper, the standard size for a reference book.

At disseminate stage, the distribution of books was carried out and used as a trial stage for the Introduction to Linguistics textbook. This stage has not been carried out because students cannot attend the campus due to the Covid-19 pandemic, so this stage's implementation is still postponed. This textbook trial is carried out in two phases, the first will be carried out at the individual level, and the second will be carried out at the small group of students. The individual trial is intended to find out typing errors, misuse of letters and writing mistakes. Trials on small group students were carried out to know the level of student interest in reading the textbooks that were developed and determine the level of ease of the textbooks to be understood by target learners.

\section{Conclusion}

Research on the development of the Introduction to Linguistics textbook has produced a textbook draft which was then developed for the Introduction to Linguistics course and has been validated by material experts and learning media experts. The validator's comments and suggestions are used as the basis for improvements and revisions to the developed Introduction to Linguistics textbook. Textbook trials were conducted to determine the level of readability and validity of the textbooks being developed. Textbook trials were postponed to be implemented due to the Covid-19 pandemic, which required students to study online. However, in general, this textbook can be used well in subsequent lectures.

\section{References}

Arifin, Zainal. (2009). Evaluasi Pembelajaran. Bandung: PT. Remaja Rosdakarya.

Bendor, J. (2007). Self Editing and Revisions. Jakarta: DP2M.

BPSDMP-PMP. (2012). Pedoman Penulisan Buku Ajar Peningkatan Kompetensi Pendidik. Jakarta: BPSDMP-PMP.

Choudhury, N. R. (1998). Teaching English in Indian Schools. New Delhi: S. B. Nangia APH Publishing Corporation.

Crystal, David. (1978). English as a global language. Cambridge: Cambridge University Press.

Degeng. I. N. S. (2001). Pedoman Penyusunan Bahan Ajar Menuju Pribadi Unggul. Surabaya: Universitas PGRI Adi Buana Surabaya. 
Hutchinson, Tom \& Eunice Torres. (1994). The textbook as agent of change. English Language Teaching Journal, 48, pp. 315-328.

Kridalaksana, Harimurti. (1984). Kamus Linguistik. Jakarta: Gramedia.

Likert, Rensis. (1932). A Technique for the Measurement of Attitudes. New York: The Science Press.

Lubis. (2004). Asesmen berkelanjutan. Konsep Dasar, Tahapan Pengembangan dan Contoh. Surabaya: UNESA University Press.

Mintowati. (2003). Panduan Penulisan Buku Ajar. Jakarta: Depdikbud.

Rachmawati, W. S. (2004). Anatomi Buku Ajar. Jakarta: Departemen Pendidikan Nasional.

Richard, J. C. \& Schmidt, R. (2002). Longman Dictionary of Language Teaching and Applied Linguistics 3rd Edition. Edinburgh: Pearson Education Limited.

Richey, Rita C., \& Klein, James D. (2007). Design and Development Research: Methods, Strategies, and Issues. New Jersey: Lawrence Erlbaum Associates.

Sahertian, W. Demaja Christiana. (2004). Pengaruh Penggunaan Bahan Ajar Dan Gaya Belajar Terhadap Hasil Belajar, Artikel.

Thiagarajan, S., Semmel, D. S \& Semmel, M. I. (1974). Instructional Development for Training Teachers of Expectional Children. Minnesota: Leadership Training Institute/Special Education, University of Minnesota.

Tiwari, S. R. (2008). Teaching of English. New Delhi: S. B. Nangia APH Publishing Corporation.

Tomlinson, B. (Ed.). (1998). Materials Development in Language Teaching. Cambridge: Cambridge University Press. Wardhaugh, Ronald \& Janet M. Fuller. (1973). An Introduction to Sociolinguistics. Oxford: John Wiley \& Sons, Inc. Webster, Merriam. (1981). Webster's New Collegiate Dictionary. New York: Merriam Webster, Inc. 